\title{
L-035なぜ自分で選んだものが好きになるのか一選択による選好の変化 の生起とその生起量を規定する要因一
}

\author{
講演者: 宮城 円 (広島文教女子大学) \\ 司会者: 中尾敬 (広島大学)
}

\begin{abstract}
夕飯の献立や就職先を決めるときなど, 我々は人生の様々な場面で自らの好みに基づいて意思決定を 行っている。その一方で, 好みは自らの意思決定それ自体によって変化することが知られており, その 現象は「選択による選好の変化 (Choice-Induced Preference Change: CIPC)」と称されている。なぜ自 らの選択によって選んだものの好みが変化するのであろうか。CIPC の生起過程については十分な検討 がなされていないが，その解明は好みのような主観的な価值基準の形成過程や，そうした基準による意 思決定過程の理解につながる。本講演では, CIPC と選択に対する主体感㧍よび報酬との関連について 検討した結果を報告する。そして, それらの知見を基に, 自分で選んだ報酬感が選んだものの価值を高 めることによって CIPC が生じるという CIPC の生起過程モデルを提案する。
\end{abstract}

第3 日 9 月27日(木) $11: 40 \sim 12: 40$

\section{L-036＼cjkstart高次認知プロセスの潜在性と顕在性一洞察問題解決と対人認知の 実験的研究一}

$\begin{array}{lr}\text { 講演者: 織田 } & \text { 涼 (東亜大学) } \\ \text { 司会者: 服部 } & \text { 雅史 (立命館大学) }\end{array}$

本研究では, 洞察問題解決および対人認知における, 無意識に遂行される潜在プロセスと, 意識的に 遂行される顕在プロセスとの相互的関係の特徵を検討した。洞察問題解決では, 意識的な問題への取り 組みが，気づきを伴わない手がかりを利用した解の探索をかえって妨げることを示す複数の実験結果が 得られた。この結果は, 顕在レベルでの努力的な課題遂行が, 潜在レベルでのアイデア生成を阻害し, 洞察による解の発見を難しくしていることを示唆する。他方, 対人認知では, 情報の想起に伴う「思い 出しにくい」という感覚が無意識に参照されると, 関連する情報が網羅的に想起され, 人物判断が変容 するという仮説を立て, 複数の実験結果がこの仮説を支持した。潜在レベルでの流暢性の感覚が, 顕在 レベルでの努力的な処理を促すことを示唆する。これらの知見を踏まえ, 高次認知における潜在プロセ スと顕在プロセスの協調的または妨害的な相互関係について考察した。 